\title{
A INFLUÊNCIA DOS AFORISMOS SAPIENCIAIS NO MITO COSMOGÔNICO DO IEPO HERMÉTICO
}

\author{
David Pessoa de Lira*
}

RESUMO: A despeito de Charles Harold Dodd ter afirmado que o

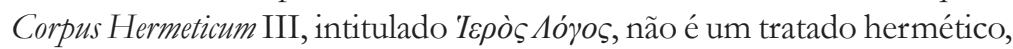
mas judaico-estoico e que não tem nenhuma afinidade com a Literatura Hermética, mesmo que Walter Scott tenha considerado o Corp. Herm. III como um tratado sem ou quase inteiramente sem sentido, é plausível que esse texto tenha sido escrito sob a influência dos aforismos sapienciais ou das sentenças gnômicas, apresentando semelhanças com vários tratados herméticos, apresentando similaridades monistas. O mito cosmogônico do

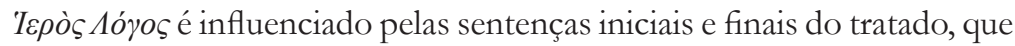
formam uma moldura e orientam todo texto. Embora seja considerado um tratado judaico-estoico, o Corp. Herm. III tem relações com os temas do hermetismo mágico-astrológico dos Papyri Graecae Magicae, tais como

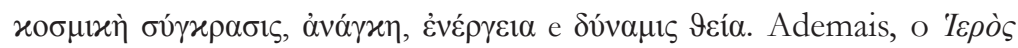

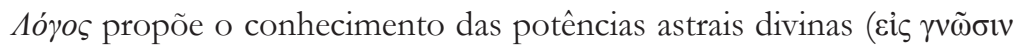
$\checkmark \varepsilon i ́ \alpha \varsigma \delta v v \alpha ́ \mu \varepsilon \omega \varsigma)$. O presente artigo objetiva, por meio de uma análise do

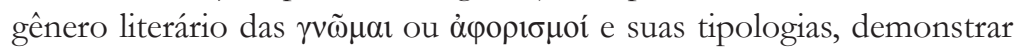
que o Corp. Herm. III é um tratado cujo monismo faz parte de toda uma tradição mágico-astrológica que subjaz ao texto religioso.

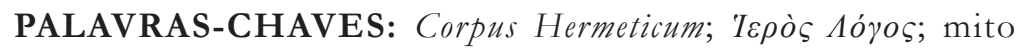
cosmogônico; sentenças gnômicas; aforismos sapienciais.

\section{THE INFLUENCE OF THE SAPIENTIAL APHORISMS IN THE COSMOGONIC MYTH OF THE HERMETIC IEPO $\Lambda$ OГO $\Sigma$}

\author{
* Professor de Língua \\ e Literatura Latinas \\ do Departamento \\ de Letras da \\ Universidade Federal \\ de Pernambuco \\ (UFPE). Líder do \\ Grupo de Pesquisa \\ Hermeneia - \\ Língua e Literatura \\ Grega e Latina da \\ Antiguidade e do \\ Medievo. \\ lyrides@hotmail.com
}

\begin{abstract}
In spite of having affirmed Charles Harold Dodd that

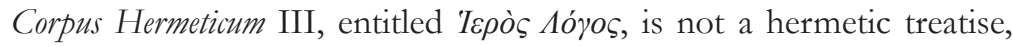
but Judaeo-Stoic one and that it has not any affinity with the Hermetic Literature, even though Walter Scott has found Corp. Herm. III as a treatise without or almost completely without sense, it is credible that this text has been written under the influence of the sapiential aphorisms or gnomic sentences, presenting monist similarities with several hermetic treatises.

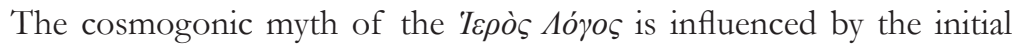
and final sentences of the treatise, which form a frame and orientate all
\end{abstract}


the text. Though the treatise is considered Judaeo-Stoic, the Corp. Herm. III has affinity with

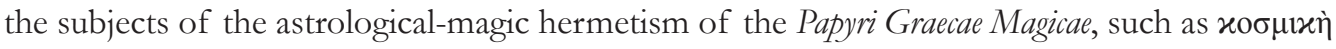

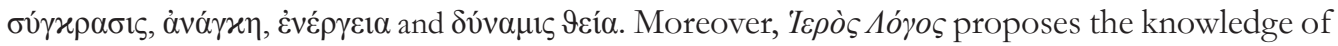

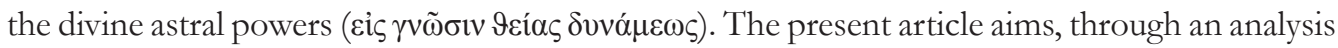
of the literary type of $\gamma v \tilde{\omega} \mu \alpha \mathrm{l}$ or $\dot{\alpha} \varphi \rho \rho \iota \sigma \mu o i$ and their typology in order to demonstrate that the Corp. Herm. III is a treatise which monism makes part of the whole astrological-magic tradition which underlies to the religious text.

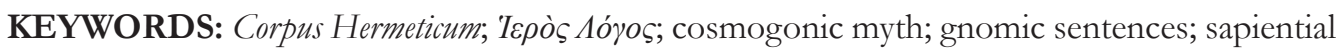
aphorisms.

\section{INTRODUÇÃO}

1 Deus é a glória de todas as coisas, o ser divino e a natureza divina. Deus é o princípio dos seres, também o noûs, a natureza e a matéria, sendo a sabedoria para demonstração de todas as coisas. O Divino é o princípio, a natureza, a energia e a necessidade, tanto o fim quanto a renovação.

1b Pois, no abismo, havia uma escuridão indefinida, água, e um sutil sopro mental, e todas essas coisas existiam no caos pela potência divina. Então uma luz santa foi enviada para cima e os elementos da substância úmida foram solidificados †pela areia†, e todos os deuses $\uparrow$ se separaram $\uparrow$ da natureza germinal. 2 E, enquanto todos os seres ainda estavam desordenados e não construídos, os [elementos] leves foram separados para o alto e os pesados foram firmados sobre a areia úmida depois que todos os seres foram separados e suspensos de maneira a serem levados pelo sopro; e o céu foi visto em sete ciclos, e os deuses, aparecendo nas formas de astros, foram articulados com todos os seus signos (...) Com os deuses em si, também a circunferência foi enrolada pelo ar, sendo conduzido em curso cíclico pelo sopro divino.

3 E cada deus levantou, pelas suas próprias potências, o que lhe tem sido ordenado: e vieram a existir feras quadrúpedes, répteis, aquáticos, voláteis, toda semente germinal, pasto e relva de toda flor, †colheram em si mesmos $\uparrow$ a semente da palingenesia, os engendramentos dos homens para a gnose das obras divinas, o testemunho ativo da natureza, o crescimento dos homens, o domínio de todas as coisas abaixo do céu, e a cognição das coisas boas; para o crescer em crescimento e o multiplicar em multidão também toda alma em carne através do curso dos deuses cíclicos †e do semear portentos †; para o reconhecimento do céu e do curso dos deuses celestes e das obras divinas e da energia da natureza não só para † sinais de coisas boas $\dagger$, para gnose de potências divinas $\dagger$ da parte que intima $\dagger$ para conhecer das coisas boas e más, mas também para descobrir todo trabalho engenhoso de coisas boas. 
4 Inicia-se para eles o viver e também o ser instruídos para o destino do curso dos deuses cíclicos, e, tendo deixado grandes lembranças das obras de arte sobre a terra, serem dissolvidos naquilo que será: †em nome através dos tempos, na fraqueza e em todo nascimento de carne animada e do fruto da semente e de toda obra de arte $\dagger$; as coisas decrescidas serão renovadas pela necessidade e pela renovação dos deuses e pelo curso do ciclo inumerável da natureza.

4b Pois o divino é toda a sincrasia cósmica, renovada pela natureza; com efeito, no Divino também a natureza se estabeleceu (tradução própria). ${ }^{1}$

Os tratados filosófico-religiosos do Corpus Hermeticum se desenvolveram no mundo greco-egípcio, na época imperial romana, principalmente entre séculos I a III da Era Comum (Filoramo, 1992, p. 377-378; Mahé, 2005, v. 6, p. 3944). Também é atestado por alguns pesquisadores que, no séc. III a.E.C, já circulavam alguns escritos herméticos de cunho mágico-astrológico, embora não necessariamente filosóficos. ${ }^{2}$

O nome de Hermes Trismegisto não é o bastante para caracterizar que um determinado livro seja hermético (Van Bladel, 2009, p. 21; Ebeling, 2011, p. 1, 7). Há textos que podem ser designados como herméticos mesmo sem a referência ao nome de Hermes Trismegisto, como por exemplo, o livro de Poimandrès (ou o Corp. Herm. I), em que não há indicação de que o visionário seja Hermes Trismegisto. É apenas uma referência do Corp.

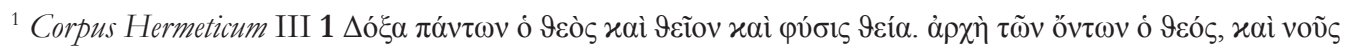

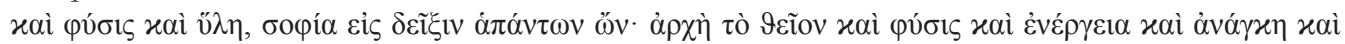

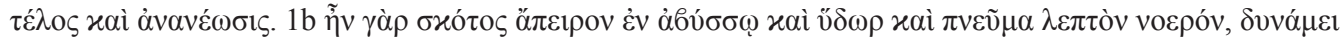

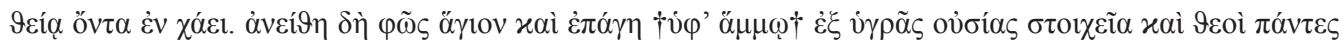

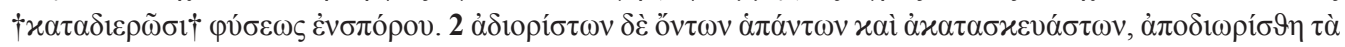

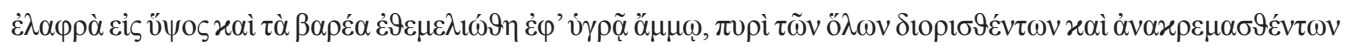

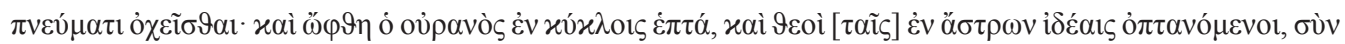

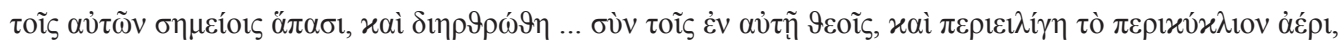

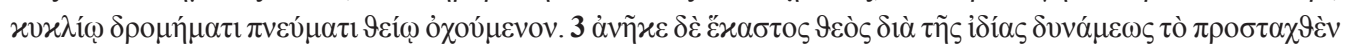

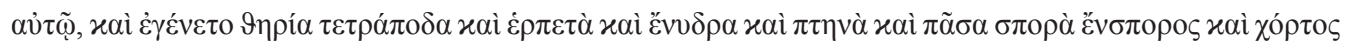

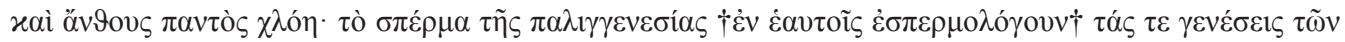

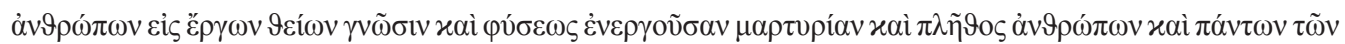

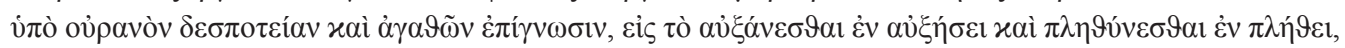

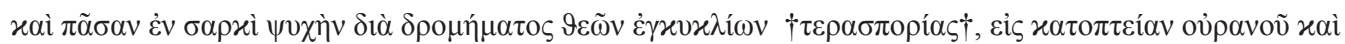

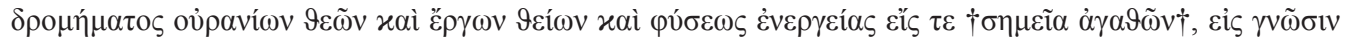

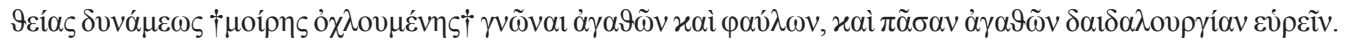

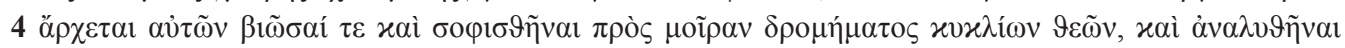

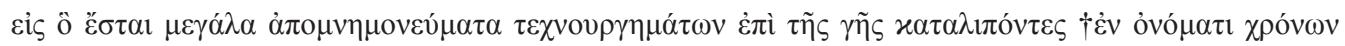

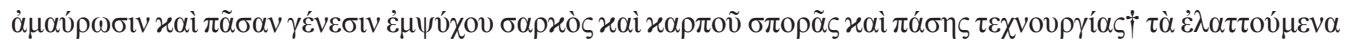

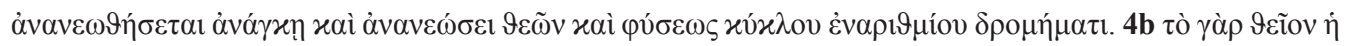

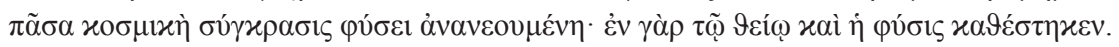

${ }^{2}$ Filoramo, 1992, p. 377-378; Mahé, 2005, v. 6, p. 3938-3939; González Blanco, 1973, p. 358. 
Herm. XIII.15 que faz pressupor isso (Dodd, 2005, p. 15). Ademais, não se pode aventar que um texto seja hermético por ter um título com o nome dessa personagem mítica. Isso porque os títulos são geralmente tardios ou submetidos a acréscimos. O Corp. Herm. I, por exemplo, possui o título E

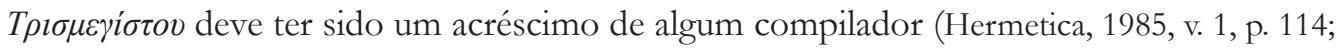
Hermetica, 1985, v. 2, p. 12).

Todos os manuscritos intitulam o tratado III do Corpus Hermeticum como E

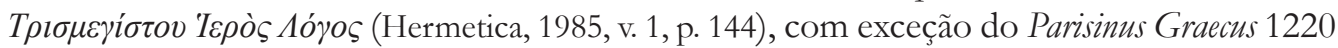

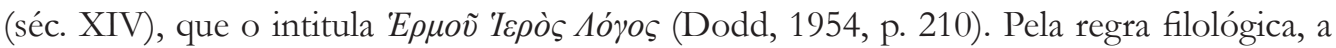
leitura mais breve é preferível e tende a se aproximar do texto original em maior ou menor grau. Assim, Arthur Darby Nock preferiu a leitura mais breve em seu texto crítico, a saber,

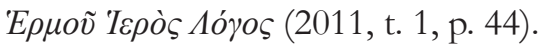

Walter Scott salienta que não há fundamento para se crer que a superinscrição do

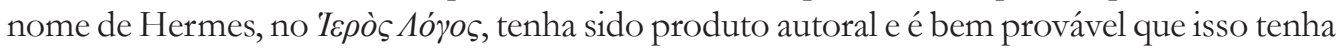
sido acrescentado posteriormente, quando o texto foi transmitido e chegou nas mãos de algum seguidor do hermetismo antigo (Hermetica, 1985, v. 2, p. 118-120). Contudo, é plausível, como ocorre em outros tratados do Corpus Hermeticum, ${ }^{3}$ que Corp. Herm. III tivesse uma espécie de cabeçalho e que isso fosse mais antigo do que o título. Ao que tudo indica, a primeira

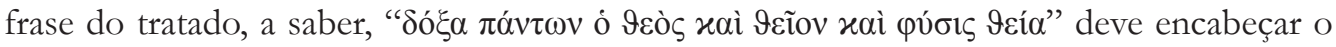
texto (Hermetica, 1985, v. 1, p. 144; Hermetica, 1985, v. 2, p. 118-120). Como se percebe nessa oração, nada há sobre Hermes Trismegisto nem o tratado o menciona. Charles Harold Dodd explica que não há nada, no Corp. Herm. III, que indique sua atribuição a essa personagem (Dodd, 1954, p. 210, n. 1). Como foi supramencionado, o nome de Hermes Trismegisto não é o bastante para caracterizar que um determinado livro seja hermético. Ademais, o adjetivo $\dot{\varepsilon} \rho \mu \alpha \ddot{x} \varsigma^{4} \varsigma^{4}$ não incide nos tratados, tampouco se deve aventar que o título deva indicar sua caracterização.

Em última análise, convém salientar que os temas e conteúdos doutrinários constituem elementos relevantes e que caracterizam a Literatura como Hermética. Assim, por hermetismo, deve-se entender o conjunto de doutrinas que integram os documentos desse movimento (Eliade, 2011, v. 2, p. 258). A ideia principal que permeia os livros herméticos filosóficos e religiosos é a da inter-relação entre Deus, o mundo e o ser humano, constituindo um conhecimento teoantropocósmico (Dodd, 2005, p. 30; Van Den Broek, 2006, p. 559ss.).

Não obstante tudo isso, Dodd afirma que o Corp. Herm.III não é propriamente um tratado hermético, mas judaico-estoico (Dodd, 2005, p. 214, n. 1). Mas, antes, ele havia afirmado que esse texto tem certa afinidade com a Literatura Hermética, embora lhe faltem características típicas do hermetismo, sendo incluído ao Corpus Hermeticum quando os textos avulsos foram coligidos (Dodd, 1954, p. 210, n. 1). Dodd analisou amplamente esse tratado

\footnotetext{
${ }^{3}$ Corp. Herm. V, VI, VII, VIII, IX, XII, XIII, XVIII.

${ }^{4}$ Exceto se a conjectura a respeito da palavra Épuaïxós, no Papiro Mágico XIII.138 (Papyrus Leidensis I 395), estiver correta. Caso contrário, não há nenhuma incidência. Cf. Preisendanz, K et al., 1974, v. 2, p. 93; Betz, H. D. et al., 1986, p. 175; Fowden, 1993, p. 171-172.
} 
e concluiu que o Corp. Herm. III é um escrito influenciado pelo judaísmo helenístico através da versão grega (LXX) das Escrituras Hebraicas no que diz respeito ao Hexaemeron, sendo reinterpretados em termos da filosofia grega, principalmente pelo estoicismo anterior a Posidônio de Apameia (100-50 a.E.C.). ${ }^{5}$

Ademais, Walter Scott afirma que o texto grego do Corp. Herm. III, nos manuscritos, é tão corrupto ${ }^{6}$ quanto sem sentido ou quase inteiramente sem sentido. Assim, para obter sentido, deve-se alterar amplamente o texto (Hermetica, 1985, v. 1, p. 144; Hermetica, 1985, v. 2, p. 110). Scott sugere que esse tratado tenha sido escrito de forma independente dos outros tratados e que ele se difere marcadamente dos outros textos do Corpus Hermeticum em característica e estilo. Entretanto, o Corp. Herm. III tem uma certa semelhança com outros tratados otimistas e com o Corp. Herm. I (com incidência mais pessimista), o qual também se difere em alguns traços dos outros libelli do Corpus Hermeticum. A hipótese da influência do

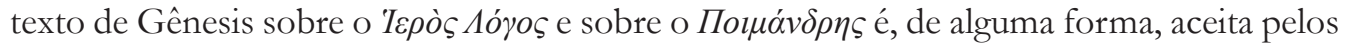
pesquisadores (Hermetica, 1985, v. 2, p. 110-112,118; Dodd, 1954, p. 210-234; Festugière, 2014, p. 482), principalmente, a partir do texto grego da Septuaginta (LXX). Entretanto, Scott levanta a hipótese de que o tipo de fusão entre o judaísmo e o estoicismo gerou uma cosmogonia semelhante àquela de Sanconíaton, como relatou Filo de Bíblos (Hermetica, 1985 , v. 2, p. 112-118).

Em detrimento da aceitação da hipótese da influência do texto do Hexaemeron de Gênesis $1(\mathrm{LXX})^{7}$ e da física estoica (Reale, 2008, v. 6, p. 41-71) sobre o Corp. Herm. III ${ }^{8}$ ou da cosmogonia semelhante àquela de Sanconíaton, como relatou Filo de Bíblos (Hermetica, 1985, v. 2, p. 112-118), ' é plausível que esse texto tenha sido escrito sob a influência dos aforismos sapienciais ou das sentenças gnômicas, apresentando semelhanças com vários tratados

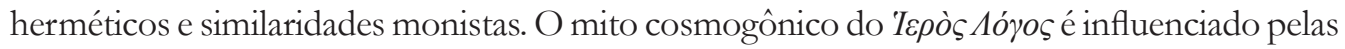
sentenças iniciais e finais do tratado, as quais formam uma moldura e orientam todo texto. Embora seja considerado um tratado judaico-estoico, o Corp. Herm. III tem relações com

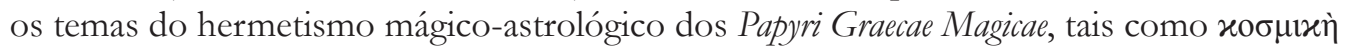

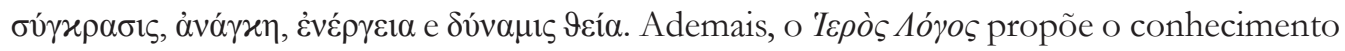

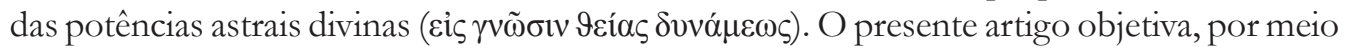
de uma análise do gênero literário das $\gamma v \tilde{\omega} \mu \alpha ı$ ou ỏ p. 410-431), demonstrar que o Corp. Herm. III é um tratado cujo monismo faz parte de toda uma tradição mágico-astrológica que subjaz ao texto religioso.

\footnotetext{
${ }^{5}$ Dodd, 1954, p. 234; Mahé, 1982, t. 2, p. 16.

${ }^{6}$ Sobre a corrupção manuscriturística do texto do Corp. Herm. III, cf. Horman, 1973, p. 43-46. As palavras e orações ininteligíveis no texto crítico do Corp. Herm. III editado por Arthur Darby Nock vêm acompanhadas de crux desperationis ( $\dagger$ ) antes e depois. Sobre a crux desperationis, cf. Rossetti, 2006, p. 106.

${ }^{7}$ Ralfs, Septuaginta, 1979, v. 1, p. 1-2.

${ }^{8}$ Hermetica, 1985, v. 2, p. 110-112,118; Dodd, 1954, p. 102, 210-234; Festugière, 2014, p. 482; Mahé, 1982 , t. 2, p. 16.

${ }^{9}$ Citado por Eusebius Caesariensis, Praeparatio Evangelica, 1.10.1-1.10.5.
} 


\section{A heterogeneidade dos tratados do Corpus Hermeticum}

Embora Tadeusz Stefan Zieliński tenha sido o primeiro a observar e classificar a heterogeneidade dos tratados do Corpus Hermeticum, chegando a classificá-los em peripatéticos, platonizantes e panteístas, é justamente a classificação de Wilhelm Bousset, de acordo com a tendência teológica, cosmológica e antropológica dos textos, que perdura hodiernamente. Bousset reuniu os tratados em três grupos, a saber: otimista (monista-panteísta), pessimista (dualista-transcendentalista) e misto. ${ }^{10}$

Os libelli do Corpus Hermeticum não são totalmente unívocos entre si em forma e conteúdo. Ademais, há tratados que conciliam doutrinas aparentemente opostas e geram contradições em si mesmas. Conforme as peculiaridades doutrinárias, amiúde, os traços imanentistas e monistas se apresentam no Corp. Herm. II, III, V, VIII, XIV e XVI; os traços transcendentalistas e dualistas incidem no Corp. Herm. I, IV, VI, VII e XIII. Em todo caso, percebe-se um imanentismo que não exclui o transcendentalismo nem um transcendentalismo que exclui o imanentismo dentro de um mesmo tratado. Por exemplo, no Corp. Herm. V, um tratado com características predominantemente monistas, fala-se da imanência de Deus, mas também da transcendência de um Deus Criador, comparando-o a um pintor e escultor. Além disso, no Corp. Herm. XI, o mais dualista dos tratados, fala-se de uma transcendência, embora não se exclua a imanência. ${ }^{11}$ Finalmente, os tratados IX-XII do Corpus Hermeticum são imanentistas e otimistas, embora se possa encontrar passagens de caráter dualista e transcendentalista (Festugière, 2014, p. 84, 465, n. 1; Johnson, 2009, p. 85-88; Eliade, 2011, v. 2, p. 431).

Destarte, os tratados podem ser agrupados, de acordo com suas doutrinas teológicas, em monistas, dualistas e mistos. Assim, como será averiguado, o Corp. Herm. III é um tratado predominantemente imanentista, panteísta, monista e otimista. Pode-se perceber que não há nenhuma crença em um Deus transcendente, tampouco se fala em um mundo arquetípico e o tema da imortalidade, predominante no livro de Corp. Herm. I, não se evidencia no Corp. Herm. III. No entanto, ele possui relações com vários tratados desse mesmo tipo e com algumas passagens dos tratados mistos (Dodd, 1954, p. 216; Copenhaver, 2000, p. 128; Festugière, 2014, p. 482).

Garth Fowden rejeita a ideia da contradição entre os vários tratados. Sua tese é de que as variações constituem um processo sequencial da غ̇ंı p. 103). Seja qual for a teoria a ser defendida, fato é que não se pode negligenciar que os tratados herméticos não são unívocos doutrinariamente e é justamente isso que ocorre nas várias contradições existentes, inclusive dentro de um mesmo tratado do Corpus Hermeticum.

Segundo Jean-Pierre Mahé, as diferenças contraditórias e inconciliáveis são quase sempre puramente redacionais. As incongruências, incoerências e contradições devem ser

\footnotetext{
${ }^{10}$ Eliade, 2011, v. 2, p. 260; Copenhaver, 2000, p. lii; Mahé, 1982, t. 2, p. 13-15, 29, 314, 441.

${ }^{11}$ Johnson, 2009, p. 85-88; Festugière, 2014, p. 84, 465, n. 1; Yates, 1964, p. 22; Eliade, 2011, v. 2, p. 260, 431; Copenhaver, 2000, p. xxxix; Ferguson, 1990, p. 250; Filoramo, 1992, v. 1, p. 378; Mahé, 2005, v. 6, p. 3940; Mahé, 1982, t. 2, p. 15, 29, 314, 441; Dodd, 2005, p. 17-25, 20, n. 2, 33, n.1.
} 
devidamente averiguadas para se compreender em que medida elas são resultado de materiais heterogêneos, seja da ação autoral de várias pessoas seja da produção em diferentes épocas e contextos pelo mesmo autor. O objetivo principal é constatar a coesão e a coerência para saber o sentido do texto (Mahé, 1982, t. 2, p. 41-42).

Se por um lado, não se pode afirmar que há contradições teológicas inconciliáveis, por outro, os textos herméticos não são unívocos. Ademais, a natureza dessas variações e contradições doutrinárias é redacional, sendo resultante de dogmas ambíguos e contraditórios de variadas correntes filosófico-religiosas da Antiguidade. Esses dogmas se agregavam às antigas sentenças herméticas gnômicas como comentários, muitas vezes, opostos. Sendo assim, as sentenças herméticas constituíam os elementos mais antigos, constantes e imutáveis, aos quais se prendiam os mais variados acréscimos redacionais. A partir da tipologia e taxonomia redacionais dos escritos filosófico-religiosos, propostas por Jean-Pierre Mahé (2005, v. 6, p. 3940; 1982, t. 2, p. 41-43), através dos graus de intervenção redacional, pode-se distinguir os diversos tipos redacionais, e determinar o nivel redacional de incidência e intervenção dos elementos doutrinais secundários na sua ordem textual (dualista-transcendentalistapessimista ou monista-panteísta-otimista).

\section{A coerência e integridade do Corpus Hermeticum III}

A priori, deve-se proceder à estrutura textual, para, depois, averiguar sua coerência e coesão. Para Arthur Darby Nock, parte do parágrafo $1 \mathrm{~b}$ e todo o $\$ 2$ constituem uma perícope distinta do $\$ 1$ a e do $\$ 3$. Ele separa os $\$ 1 \mathrm{~b}-2$ dos $\$ 1$ e 3 . Quanto ao $\$ 4$, ele se constitui como unidade autônoma, mas é dividido em dois subparágrafos e a sentença final é uma espécie de sumário

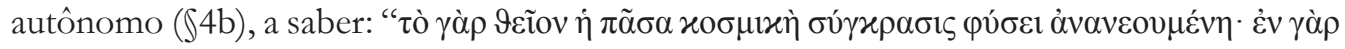

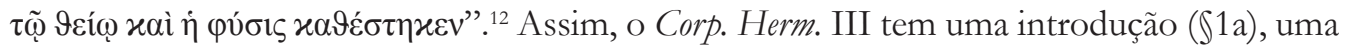
conclusão ( $(\mathbb{4} \mathrm{b})$, e o desenvolvimento em três partes: a cosmogonia (\$1b-2), a produção $(\$ 3)$ e a dissolução (\$4a). Festugière e Scott defendem a seguinte delimitação: introdução (\$1a), cosmogonia (\$1b-2), aparição dos sete círculos celestes (\$2b), a produção dos animais e vegetais (\$3a), a produção do homem e seu trabalho de produção. No entanto, Festugière segue Nock na divisão do $₫ 4$ e Scott pressupõe que a frase inicial seja o título, começando

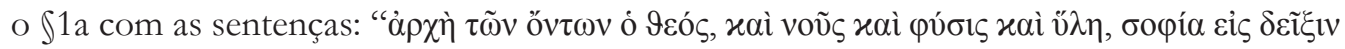

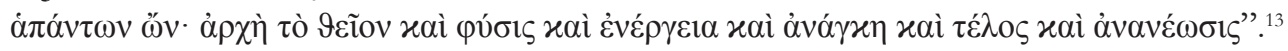

Essas sentenças iniciais devem tematizar os pontos principais sobre os quais o texto há de discorrer: 1) sobre o princípio; b) sobre a natureza; 3) sobre a energia e a necessidade; 4)

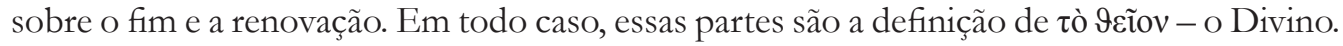

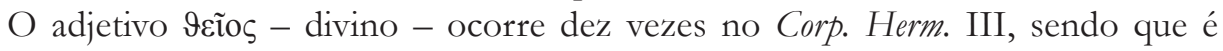

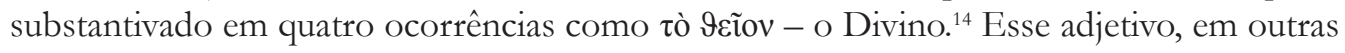

\footnotetext{
${ }^{12}$ Nock, 2011, t. 1, p. 46 (Hermès Trismégiste. Corpus Hermeticum).

${ }^{13}$ Nock, 2011, t. 1, p. 44 (Hermès Trismégiste. Corpus Hermeticum).

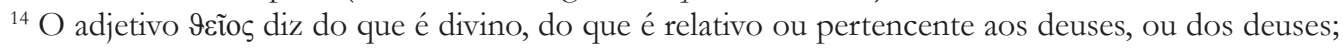
sagrado para um deus, santo; super-humano; augusto, sublime; extraordinário, maravilhoso. Referente à
} 


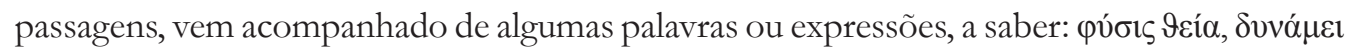

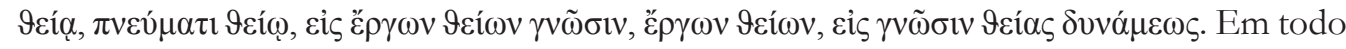
o Corpus Hermeticum, essa palavra ocorre sessenta e três vezes, sendo que é mais usado nos tratados III, IV e X. Entretanto, o emprego substantivado é mais usual no Corp. Herm. III, embora incida no Corp. Herm. II.4; IV.6; X.19; XI.21.

Poder-se-ia esperar que, depois de ter mencionado ó $\vartheta \varepsilon \grave{s} \varsigma$, o texto descrevesse uma teologia do Deus que é pai, sábio, bom etc., o que é comum na Literatura Hermética (Dodd, 2005, p. 13-14). Pelo contrário, o texto se propõe a abordar o assunto sobre as ações dos deuses astrais que separam os seres da natureza germinal (Corp. Herm. III.1b), os quais também aparecem em forma de astro e se articulam com os signos, e com os quais a natureza superior é articulada de acordo com os deuses que ela continha (Corp. Herm. III.2), sendo que cada um deles, segundo sua potência, produziu o que era devido (Corp. Herm. III.3), e, por último, produziram o ser humano com finalidades específicas (Corp. Herm. III.3) e o ser humano começou a viver e ser instruído para o destino dos deuses cíclicos (Corp. Herm. III.4).

O emprego do adjetivo $\vartheta \varepsilon i ̃ o \varsigma$ faz pressupor que se trata de algo relativo aos deuses astrais $^{15}$ e nada indica que se trata de um Deus Todo-Poderoso que rege toda criação. Esse

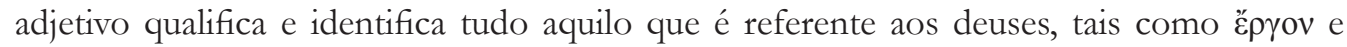

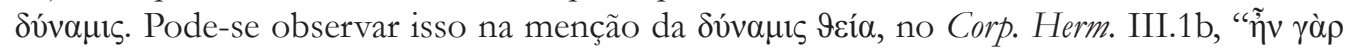

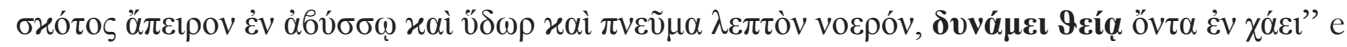

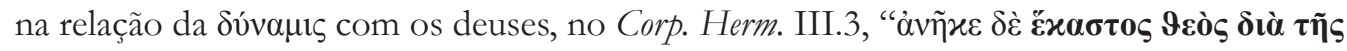

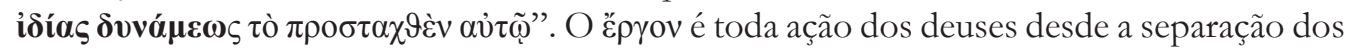
seres da natureza germinal até a produção da semente dos engendramentos dos homens (Corp. Herm. III.1b-3).

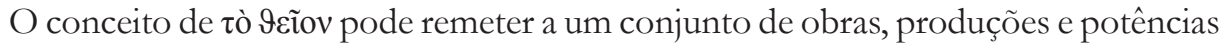
dos deuses astrais e não se trata da Divindade em termos absolutos e concretos. Trata-se de uma divindade em termos abstratos como se vincula sua definição na conclusão do texto. Ademais, o texto insiste na divindade da natureza (Festugière, 2014, p. 482). O ser ou a coisa divina é pura sincrasia ou combinação cósmica, que se renova pela natureza, já que é nas coisas sublimes que a natureza se estabelece (Corp. Herm. III.4b).

O Corp. Herm. III.1 a e Corp. Herm. III.4b formam uma moldura que enquadra todo o texto, de maneira a formar um todo orgânico, formando uma unidade de sentido. O texto cumpre o propósito de apresentar o ser divino, começando com uma cosmogonia, depois passa a explicar a natureza, para, em seguida, descrever a condução da vida humana e, por fim, discorre sobre a diminuição e a renovação. Pode-se inferir que o Corp. Herm. III não é um resumo da cosmogonia do Poimandrēs nem se pode presumir que seja um texto

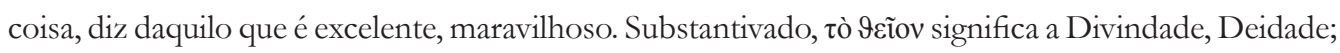
abstratamente, divindade, ser divino. No plural, $\tau \grave{\alpha} \vartheta \varepsilon \tilde{\imath} \alpha$, significa coisas divinas, religião, oráculos, culto. Como substantivo, também significa enxofre (para purificação ou incinerar) (Cf. Morwood; Taylor, 2002, p. 63; Liddell; Scott; Jones, 1996, p. 690-661).

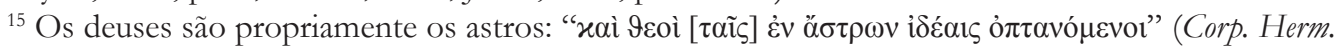
III.2). Cf. Mahé, 1982, t. 2, p. 219. 
incompleto ou um fragmento de uma obra mais ampla (Hermetica, 1985, v. 2, p. 110-112,118; Dodd, 1954, p. 215). Assim, o drástico tratamento manuscriturístico proposto por Walter Scott é desnecessário (Hermetica, 1985, v. 1, p. 144). O estilo do Corp. Herm. III é emaranhado e, muitas vezes, incorreto, mas não se pode presumir que seu autor fosse tão familiarizado com a língua grega (Dodd, 1954, p. 210).

\section{As Características das Tngmai e o gênero do IEPoz $\Lambda$ oroz do Corp. Herm. III}

Amiúde, segundo Jean-Pierre Mahé, a Literatura Hermética foi originalmente constituída por sentenças gnômicas ou sapienciais ( $\gamma v \tilde{\omega} \mu \alpha \imath$ ou $\lambda o ́ \gamma l \alpha)$, que, sendo de caráter teórico, expressam certa consideração em relação às naturezas dos seres e das coisas sem expressar necessariamente uma ação. As características semânticas e formais das sentenças gnômicas teóricas são tipicamente retóricas (Mahé, 1982, t. 2, p. 412, 414-416). ${ }^{16}$

A priori, convém salientar que, aqui, não se diferencia $\gamma v \omega ́ \mu \eta$ de $\alpha \dot{\varphi} o ́ p ı \sigma \mu \alpha$ ou ả

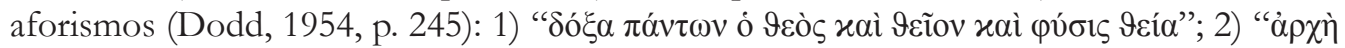

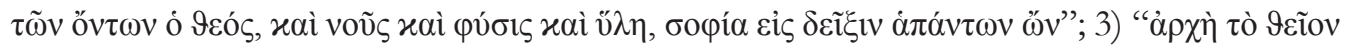

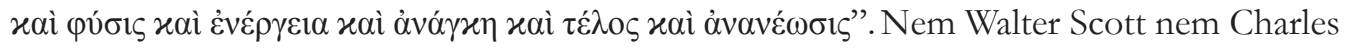
Harold Dodd fazem menção à última sentença, mas ela também apresenta estrutura formal

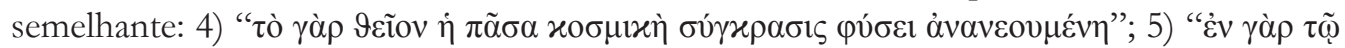

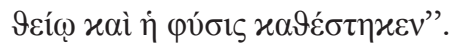

$\mathrm{Na}$ primeira sentença "Deus é a glória de todas as coisas, o ser divino e a natureza divina" e na terceira "O Divino é o princípio, a natureza, a energia e a necessidade, tanto o fim quanto a renovação", existe uma generalidade do sujeito que resulta na completude ou na totalidade da espécie e não há um qualificador especial (aquele que, qualquer que, nada, tudo, todo que, cada). A generalidade do sujeito, por sua vez, resulta da amplitude

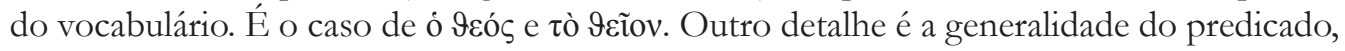

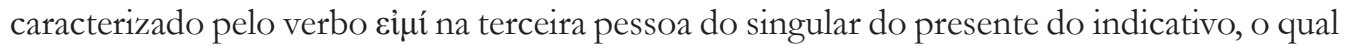
se encontra elíptico no grego (Mahé, 1982, t. 2, p. 414).

A segunda sentença "Deus é o princípio dos seres, o nô̂s, a natureza e a matéria, sendo a sabedoria para demonstração de todas as coisas", apresenta a mesma estrutura

\footnotetext{
${ }^{16}$ No entanto, Mahé não procede a partir das teorias retóricas aristotélicas para definir as sentenças. Em lugar disso, emprega a definição de Hermógenes de Tarso (séc. II E.C.). Assim, do ponto de vista

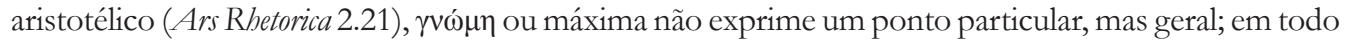
caso, devem-se evitar generalidades. As máximas são entimemáticas ou dedutivas (Anderson Jr., 2000, p. 30-32). Quanto às caraterísticas formais das sentenças, Mahé segue as sugestões de F. Desbordes sobre as formas e estruturas das sentenças de Publilius Syrus(85-43 a.E.C.). Cf. Desbordes, 1979, p. 75. ${ }^{17}$ Sobre $\gamma v \omega ́ \mu \eta$ e $\alpha \dot{\varphi} \rho \rho \imath \sigma \mu o ́ s$, Mahé se baseia em Hiérocles, neoplatônico do séc. V E.C., que usava

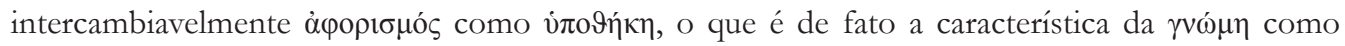
sentença sapiencial ou ensinamento. Cf. Horna, 1935, p. 77; Russo, 1977, p. 49-63, 52-63; Rossetti, 2006, p. 341-342, 370.
} 
das anteriores, exceto pela oração subordinada adjetiva que serve como um comentário (destacado em negrito). A oração principal foi comentada pela oração subordinada. Tipologicamenta, trata-se de uma sentença comentada. O mesmo acontece com a quarta sentença, a saber: "Pois o divino é toda a sincrasia cósmica, sendo renovada pela natureza" (Mahé, 1982, t. 2, p. 425-426).

Esses comentários são de materiais diversos e podem ser retirado do próprio texto ou de outros tratados do Corpus Hermeticum, ou ainda de outros textos não herméticos, com a finalidade de elaborar uma especulação. Nessa última sentença, existe toda probabilidade

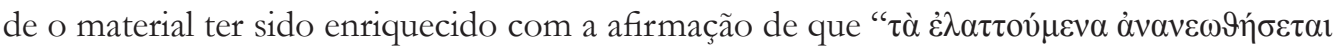

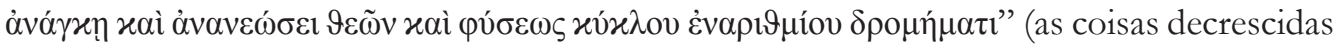
serão renovadas pela necessidade e pela renovação dos deuses e pelo curso do ciclo inumerável

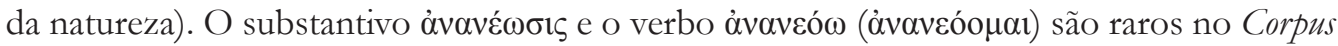
Hermeticum, incidindo no Corp. Herm. III.1, 4; IX.6; XI.15, tratados com características monistas, imanentistas, panteístas e otimistas.

Assim, no Corpus Hermeticum IX.6, reza-se o seguinte:

Uma, com efeito, é a sensação e a intelecção do mundo: fazer todas as coisas e de desfazer para si, como instrumento da vontade de Deus. E assim sendo feito instrumento, a fim de que todas as coisas façam energicamente tudo nele mesmo; e dissolvendo todas as coisas, renove; e, por isso, as coisas tendo sido liberadas, como o bom lavrador da vida, trazendo-lhes renovação na metabolé e na existência. Não existe o que ele não vivifica; e trazendo todas as coisas, vivifica; e, semelhantemente, o espaço é também Demiurgo da vida. (tradução própria). ${ }^{18}$

O mundo é o que há de mais sensível e perceptível (Mahé, 1982, t. 2, p. 375). As características monistas, imanentistas, panteístas e otimistas estão presentes no texto, pelo

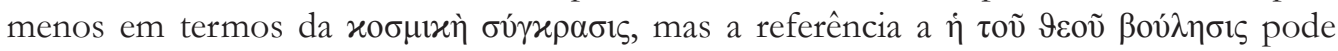
pressupor uma teologia diferente da do Corp. Herm. III. Nada há, no Corp. Herm. III, que

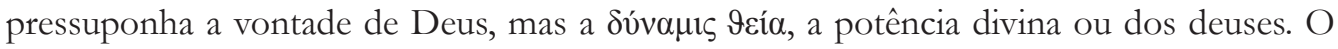
tema da admiração e contemplação do mundo não é raro nos tratados herméticos, como incide no Corp. Herm. III. 3; IV. 2; V. 3-5; IX. 6 (Mahé, 1982, t. 2, p. 237). Ademais, o que há em comum entre os dois tratados, ou pelo menos nessa passagem, e o tratado três é o

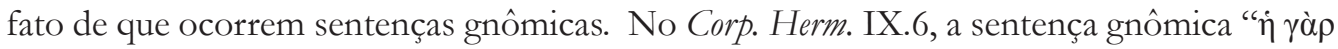

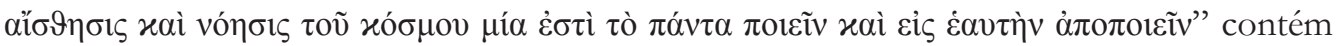
oposição, o que constitui a autonomia do enunciado (Mahé, 1982, t. 2, p. 414-415). Em todo

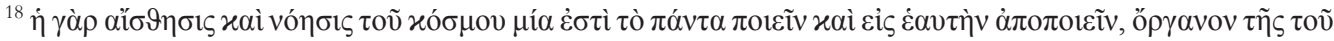

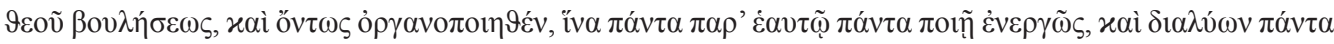

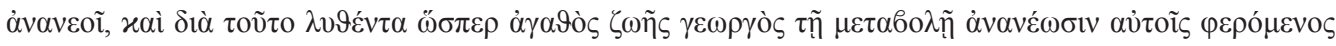

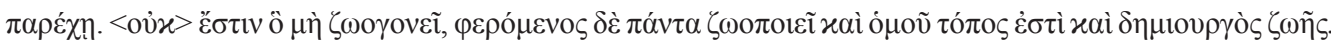


caso, as formas dos comentários que se agregam às sentenças não são mais iguais à $\gamma v \omega ́ \mu \eta$ (Mahé, 1982, t. 2, p. 425-426).

Por fim, na quinta sentença “com efeito, em Deus também a natureza se estabeleceu”, há duas características importantes. A primeira diz respeito ao fato de que essa é encadeada com a anterior "pois o divino é toda a sincrasia cósmica, sendo renovada pela natureza" por meio da partícula conjuntiva causal-explicativa yó $\rho .{ }^{19}$ Trata-se de uma sentença autônoma que se vinculou a outra por meio de uma conjunção, que, segundo Mahé, marca a presença de todo um conglomerado de várias sentenças (Mahé, 1982, t. 2, p. 425). Diferentemente das três anteriores, que são sentenças isoladas que se associam (mesmo que uma seja comentada), a quinta é tipologicamente uma sentença encadeada. No entanto, essa sentença não perde sua característica formal. Ademais, o aforismo anterior também possui uma ligação por meio

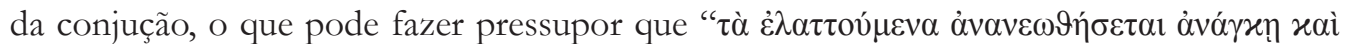

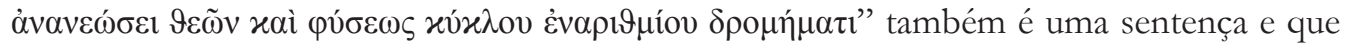

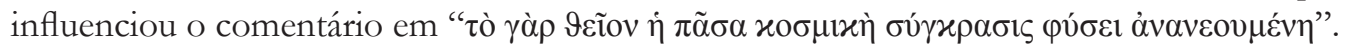

Uma segunda característica para a sentença “com efeito, em Deus também a natureza se estabeleceu" diz respeito ao predicado. Como foi supramencionado em relação às primeiras sentenças, também, aqui, há uma generalidade do sujeito que resulta na completude ou na totalidade da espécie e não há um qualificador especial. Quanto à generalidade do predicado, caracterizado pelo verbo, esse deveria vir na terceira pessoa do singular do presente do indicativo (Mahé, 1982, t. 2, p. 414). Entretanto, ele é aoristo de $\varkappa \alpha \vartheta i ́ \sigma \tau \eta \mu$, a saber, $x \alpha 9 \varepsilon ́ \sigma \tau \eta \varkappa \varepsilon v$. Em todo caso, como se está referindo a uma sentença gnômica, não se pode negligenciar o fato de que, aqui, se trata de um aoristo gnômico. O sentido de um aoristo gnômico implica uma ação presente e não de narrativa do passado. Onde se usa o presente no português, no grego emprega-se o aoristo gnômico, principalmente em sentenças sapienciais. Assim, expressa-se, sem consideração de tempo, uma verdade da experiência ou descrevem-se verdades gerais. ${ }^{20}$

Pode-se constatar que, amiúde, as sentenças são comentadas por via especulativa. Do ponto de vista do conteúdo, são sentenças de comentários carregados de juízo de valor (elementos axiológicos). Diferente da forma das sentenças primitivas, os comentários geralmente apresentam os verbos no particípio e são sintaticamente orações subordinadas reduzidas ou orações coordenadas aditivas assindéticas. Além disso, elas podem ser resultado da introdução de uma conjunção causal ou explicativa em uma determinada oração (Mahé, 1982, v. 2, 422-426).

Não obstante tudo isso, as sentenças podem ser comentadas com a ajuda de materiais mitológicos. Semelhantes àquelas supracitadas, elas são comentadas, mas podem apresentar uma aparente característica narrativa ao empregar o aoristo por decorrência da junção da

\footnotetext{
${ }^{19}$ Sobre partícula conjuntiva causal-explicativa $\gamma$ ó $\rho$, cf. Liddell; Scott; Jones, 1996, p. 1102; Ragon, 2011, p. 284; Blass; Debrunner; Funk, 2009, p. 232, 234, 235; Rusconi, 2003, p. 301; Betts; Henry, 2010, p. 41, 159; Betts, 2010, p. 152; Morwood; Taylor, 2002, p. 113; Liddell; Scott; Jones, 1996, p. 565-566; Delatte; Govaerts; Denooz, 1977, p. 69-70.

${ }^{20}$ Sobre o aoristo gnômico, cf. Ragon, 2012, p. 212; Betts; Henry, 2010, p. 56; Blass; Debrunner; Funk, 2009, p. 171-172, 177-178, 192, 259; Jay, 1994, p. 250, 252.
} 
forma das sentenças herméticas primitivas (com aoristo gnômico) a um mito adaptado. Em um determinado tratado, podem incidir sentenças isoladas, associadas, encadeadas e comentadas. A transformação de uma sentença isolada em uma sentença mitificada indica a gênese do tratado, mas nem sempre indica a forma primitiva (Mahé, 1982, t. 2, p. 416, 422-426).

De qualquer maneira, no Corp. Herm. III, não há sentenças comentadas mitificadas. O tipo de comentário que foi visto até agora é especulativo. No entanto, ainda há comentários que, segundo Jean-Pierre Mahé, são comentários mitificados. Ele exemplifica isso a partir do Corp. Herm. VIII.2-3. Mahé chama a atenção à forma esférica do Todo como uma caverna (ơvvipov) e que, segundo ele, deve constituir o motivo da "Alegoria da Caverna" que incide na República de Platão. Embora ele denomine a "Alegoria da Caverna" de mito da caverna, é sabido que se trata de uma alegoria e não de um mito. ${ }^{21}$ De qualquer forma, ele exemplifica uma alusão como comentário a partir da República, VII. 517 (Mahé, 1982, t. 2, p. 427). ${ }^{22}$ Tudo isso é um motivo, de um tema recorrente de caráter mitológico que se pode chamar de mitologema. ${ }^{23}$

É bastante plausível que as sentenças gnômicas do Corp. Herm. III sejam a parte primitiva do tratado e que tenha sido a partir das afirmações dessas $\gamma v \tilde{\omega} \mu \alpha$ que o tratado tenha se desenvolvido. Como se pôde notar, o aspecto dessas sentenças são monistas, imanentistas, panteístas e otimistas. As sentenças são, em geral, muito simples e possuem uma tipologia de comentários e encadeamento menos rebuscados, o que pode pressupor toda a gênese do texto.

Segundo Anna Van den Kerchove (2012, p. 65-66), as intervenções do discípulo, a explanação das doutrinas e a indicação (ou endereçamento) do destinatário ao qual o mestre se dirige constituem os critérios importantes para diferenciar o gênero literário dos tratados herméticos. Baseando-se nos critérios apontados por Van den Kerchove, os tratados do Corpus Hermeticum são agrupados em quatro categorias segundo o gênero: 1) discursos, sermões (Corp. Herm. VII, XVIII; 2) epístolas (Corp. Herm. XIV, XVI); 3) lições orais dialogadas, com: a) uma única questão do discípulo (Corp. Herm. VIII, IX, XI); b) questões banais do discípulo (Corp. Herm. XVII); c) comprometimento do discípulo (Corp. Herm. I, II, IV, X, XII, XIII); 4) lições orais não-dialogadas (Corp. Herm. III, V, VI) ${ }^{24}$

\footnotetext{
${ }^{21}$ Abrão, 2004, p. 52-53.

${ }^{22}$ Acerca da palavra övtpov, cf. Morwood; Taylor, 2002, p. 36; Liddell; Scott; Jones, 1996, p. 167. Sobre a "Alegoria da Caverna", cf. Platão, Res Publica, VII. 514a-517c.

${ }^{23}$ Sobre o motivo, leitmotiv, motif, cf. Defina, 1975, p. 81-82. Sobre mitologema, cf. Jung; Kerényi, 2012, p. 15-17; Kerényi, 2015, p. 221-224, 232-235.

${ }^{24}$ Van den Kerchove, na verdade, fala de cinco categorias de toda a Literatura Hermética: os discursos e sermões; epístolas; coletâneas de sentenças, lições dialogadas e lições não-dialogadas. Os tratados do Corpus Hermeticum, como um todo, não se apresentam em forma de coletâneas de sentenças. Os textos em forma de coletâneas de sentenças são o Stobaei Hermetica 11 e as Definições Herméticas Armênias. Essa forma possivelmente deve estar na origem dos escritos do Corpus Hermeticum, mas não na sua forma final. Por esta razão, aqui, é preferível falar somente de quatro categorias, nas quais Van den Kerchove agrupa estritamente os tratados do Corp. Herm.
} 
Percebe-se que as lições orais, ou seja, os textos de gênero instrucional (didático) foram divididos em dialogados e não-dialogados. De maneira geral, os dialogados são caracterizados pela intervenção do discípulo. Nos diálogos do Corpus Hermeticum, as dramatis personae são geralmente Hermes Trismegisto (como mestre), Asclépios, Tat e Amon (como discípulos), mas pode haver outras personagens, como Poimándres, Noûs e Agathòs Daîmon (como entidades ou mestres divinos). ${ }^{25}$

O Corp. Herm. III não é diálogo nem se pode descrevê-lo como instrução homilética (sermão). Nenhuma personagem, como Hermes Trismegisto, Asclépios, Tat e Amon etc., é mencionada (Festugière, 2014, p. 482). Segundo Festugière, o Corp. Herm. III é um discurso

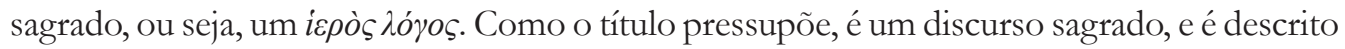
por Festugière como um hino cosmogônico prosaico. Sua cosmogonia não se assemelha àquela do livro de Poimandrès, mas possui uma apresentação desde a gênese ao fim do mundo (Festugière, 2014, p. 482). Sendo assim, o acontecimento narrado no mito é arquetípico

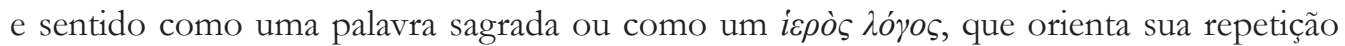
como os deuses fizeram in illo tempore, no início (à $\rho \chi \eta ́)$. Tudo o que os deuses fazem, o ser humano repete. ${ }^{26}$ A pergunta que se deve fazer é: o que, na cosmogonia do Corp. Herm. III, os homens devem imitar?

Se, por um lado, não há sentença comentada mitificada no Corp. Herm. III, por outro lado, existe um mito cosmogônico. Com exceção do Poimandrēs, a leitura dos tratados do Corpus Hermeticum é muito linear e monótona, marcada por diálogo e uma linguagem piedosa (Mahé, 1982, t. 2, p. 408). Em geral, a incidência de narrativas mitológicas nos tratados do Corpus Hermeticum não é expressiva, exceto, no Poimandrēs. E comparado a outros movimentos filosóficos e religiosos da Antiguidade, o hermetismo não se prendia a narrativas mitológicas (Mahé, 1982, t. 2, p. 428; Dodd, 2005, p. 98; Dodd, 1954, p. 244-245).

Como já se mencionou, o livro de Poimandrēs foi baseado no Hexaemeron do livro de Gênesis na versão grega da Septuaginta (Mahé, 1982, t. 2, p. 16), que descreve a criação em seis dias. Dodd afirma o mesmo em relação ao Corp. Herm. III. De acordo com Mahé, os mitos não são anteriores e autônomos em relação às sentenças gnômicas. Por exemplo, os mitos, em Poimandrès, dependem essencialmente das sentenças gnômicas. Segundo ele, as sentenças não só ajudam no papel decisivo de reescrever o mito, mas também, por consequência, reinterpretam-no. A incidência das sentenças intercaladas em cada episódio da narrativa mitológica do Poimandrès é decisiva. Destarte, sua teoria é de que as sentenças não são inserções ou de articulações. Elas se destinam a explicar o mito, que Mahé julga como tardio e posterior em relação às sentenças no processo redacional (Mahé, 1982, t. 2, p. 428). De igual modo, isso ocorre com o Corp. Herm. III

Do ponto de vista retórico, a narrativa mitológica faz parte das formas e gêneros discursivos dominados pela figuratividade. Como na figuratividade da fábula, o mito também se apresenta, com seu aspecto figurativo, como um exemplum ou $\pi \alpha \rho \alpha ́ \delta \varepsilon \imath \gamma \mu \alpha$ retórico (Bertrand,

\footnotetext{
${ }^{25}$ Cf. Dodd, 2005, p. 13; Hermetica, 1985, v. 1, p. 2-3; Mahé, 2005, v. 6, p. 3940.

${ }^{26}$ Cf. Eliade, 2010, p. 313-354; Croatto, 2010, p. 229-231.
} 
2003, p. 154-155, 215). A fábula, a parábola e o mito são composições que podem ser usadas como exempla retóricos (Palmer, 1999, p. 582). A fábula expressa figurativamente o que a moral condensa abstratamente (Bertrand, 2003, p. 213-214). O par fábula/ moral procede segundo as regras retóricas (Ars Rhetorica 2.22), em que a persuasão se dá por meio do exemplum e por meio de raciocínio ou dedução (entimema). ${ }^{27} \mathrm{O}$ mito, sendo um texto figurativo, também pode ser empregado como exemplum (Palmer, 1999, p. 582).

$\mathrm{Na}$ Ars Rhetorica, Aristóteles descreve sobre o uso do exemplum ou $\pi \alpha \rho \alpha ́ \delta \varepsilon \imath \gamma \mu \alpha$ e sua natureza. Assim, ele afirma:

E o que resta falar sobre as provas comuns a todos os gêneros, já que realmente tem sido falado sobre as próprias. Mas as provas comuns são de dois gêneros: exemplo e entimema; com efeito, a máxima é parte do entimema. Assim, primeiramente falemos sobre o exemplo: pois é semelhante à indução, e a indução é um princípio. E [há] duas formas de exemplos: pois uma é a forma do orador falar os fatos ocorridos; a outra é a dele compor. E desta, uma é a parábola e as outras são as fábulas, como as esópicas e as líbias (tradução própria). ${ }^{28}$

A tematização mais profunda é oriunda da função histórica exemplar ( $\left.\pi \alpha \alpha_{\alpha} \delta \varepsilon \_\gamma \mu \alpha\right)$ do mito do Corp. Herm. III.1b-2, que constitui suas provas ( (Eliade, 2010, p. 350). Em todo caso, é plausível que o autor ou redator do Corp. Herm. III tenha procedido de acordo com o modelo retórico ao usar o mito de modo ilustrativo. $\mathrm{O}$ mito cosmogônico, nesse tratado, depende das sentenças, sem as quais não se poderia servir como ilustração ou exemplum retórico. Todo mito é exemplar e paradigmático. No entanto, essa narrativa mitológica não é decisiva para interpretar o tratado. Ela depende de detalhes temáticos das sentenças.

\section{Conclusão}

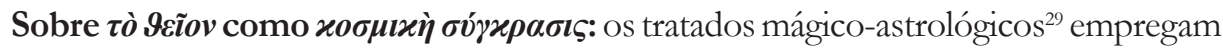
vários termos e ideias que incidem no Corp. Herm. III. O controle sobre o mundo telúrico

${ }^{27}$ Cf. Bertrand, 2003, p. 214; Palmer, 1999, p. 582.

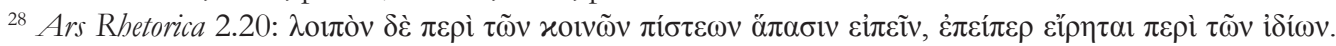

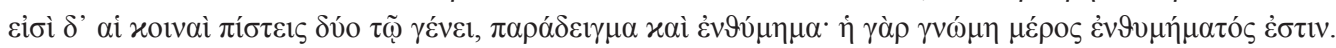

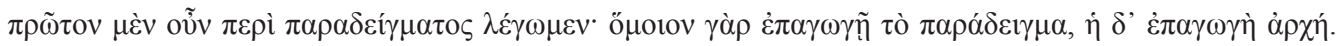

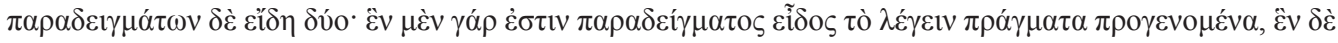

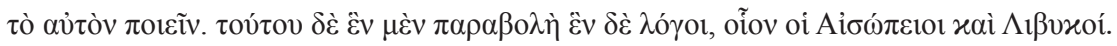

${ }^{29}$ Sobre o hermetismo e sua relação com de práticas astrológicas, mágicas, alquímicas, teúrgicas e pseudocientíficas, cf. Fetugière, 2014, p. 105-324. O nome de Hermes Trismegisto está associado a vários papiros de caráter mágico, astrológico e alquímico. O Papiro Berolinensis 21243 é o papiro mágico mais antigo, que remonta ao período augustano. Foi através dos Papyri Graecae Magicae que, primeiramente, se relacionou o nome de Hermes Trismegisto a textos gregos. Os Papiros Astrológicos (Iatromatemáticos e Botânicos) foram inicialmente divulgados a partir do séc. I a.E.C. e amplamente 
ou terrestre por meio de certas práticas de observação e conhecimento da simpatia que se estabelece entre os seres astrais e terrestres. ${ }^{30}$ Além disso, busca-se um conhecimento para interpretação dos prognósticos, da adivinhação e das propriedades ocultas que constituem as substâncias dos vegetais e dos poderes astrais (Yates, 1964, p. 47-48; Fowden, 1993, p. 2, 87-94). Na subdivisão do hermetismo mágico-astrológico, ainda há escritos relacionados à

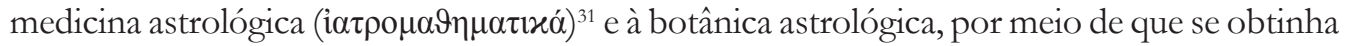
dados para diagnosticar e para curar as doenças. Na Antiguidade, a astrologia, assim como a medicina, não era somente uma ciência, mas também uma arte de saber proceder $(\tau \varepsilon ́ \chi v \eta){ }^{32}$ No Corp. Herm. III, a ideia da combinação cósmica está presente através das interações entre os seres, inclusive, com o ser humano. Como já foi supramencionado, o ser humano é contemplador da criação dos deuses e deve descobrir todo trabalho engenhoso de coisas

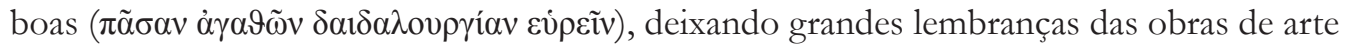

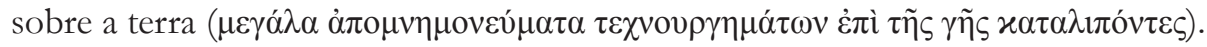

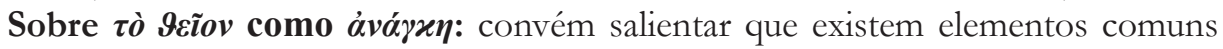
entre o hermetismo filosófico-religioso e o hermetismo mágico-astrológico, principalmente no que concerne à astrologia, embora não recorram e interpretem da mesma forma. A contradição incide entre essas duas categorias de hermetismo na medida em que o hermetismo filosófico-religioso assume a doutrina da progressão da alma através dos mundos materiais e espirituais; e o hermetismo mágico-astrológico, por sua vez, nega que o homem possa

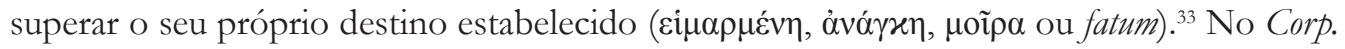

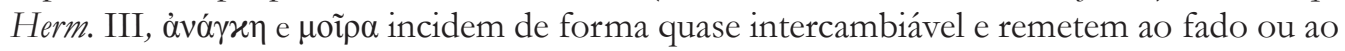
destino que o homem deve cumprir.

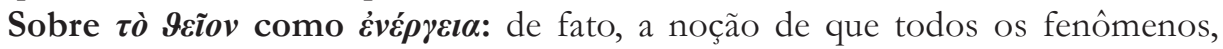

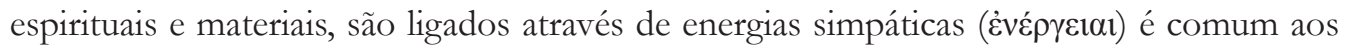
escritos herméticos mágico-astrológicos e filosófico-religiosos, o que se pode atestar no Corp.

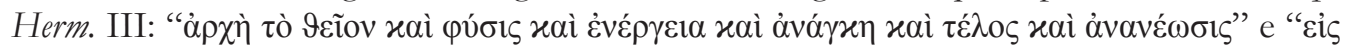

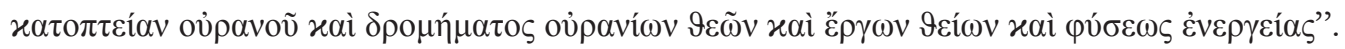
A ideia de contemplação da criação e do céu tem relação com a astrologia. Os tratados herméticos filosófico-religiosos também tendem a expor essa noção amplamente, como é o

lidos já no séc. I E.C. Os Papiros Alquímicos são os mais tardios, sendo datados do período romano quando a alquimia começou a se formar. Em todo caso, os Papyri Graecae Magicae são documentos, amiúde, datados do período entre os séc. II a. E.C. e IV E.C., escritos em grego, copta e demótico. Cf. Ebeling, 2011, p. 11; Copenhaver, 2000, p. xxxii, lxx, lxxvi; Fowden, 1993, p. 95-115, 117-120, 160. ${ }^{30}$ Sobre $\sigma 0 \mu \pi \alpha \dot{\alpha} \theta \varepsilon 1 \alpha$, cf. Fowden, 1993, p. 2, 75-78; Yates, 1964, p. 44-47.

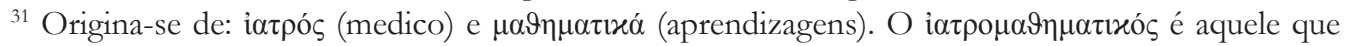
exerce ou pratica a medicina em conjunção com as artes astrológicas. Cf. Liddell; Scott; Jones, 1996, p. 816, 1072. Cf. Eliade; Couliano, 2009, p. 170.

${ }^{32}$ Cf. Van Den Kerchove, 2012, p. 1; Fowden, 1993, p. 2, 78; Cumont, 1929, p. 157; Eliade; Couliano, 2009, p. 170.

${ }^{33}$ Cf. Van Den Broek, 2006, p. 488; Copenhaver, 2000, p. xxxii; Fowden, 1993, p. 75-78, 91-94, 116120. Van Bladel, 2009, p. 5; Yates, 1964, p. 21-22, 33-35, 44-45. 


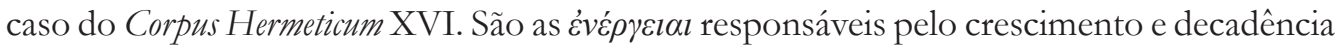
dos seres e também constituem a origem das obras de artes, das ciências e de toda atividade humana (Fowden, 1993, p. 76-77). Além disso, convém frisar que o ser humano vive uma vida cíclica, marcada, como em toda natureza, pela rotação, que se chama renovação (i் $\delta \dot{\varepsilon}$

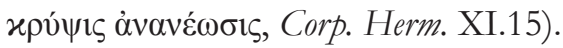

Não obstante tudo isso, nas religiões antigas, como a egípcia, por exemplo, magia e religião (ou culto e práticas mágicas) eram intrinsecamente associadas, de modo que não se podia perceber tal distinção, nem onde uma terminava e outra começava (Cumont, 1929, p. 86-87). A validade para uma distinção entre religião e magia está no simples fato de que uma procura se submeter ao controle do poder divino e a outra busca controlar os poderes divinos. Quiçá essa seja uma distinção clássica válida, não é necessariamente clara. Ao observar as formas da religião greco-romana, pode-se deparar com uma busca constante de benefícios para o ser humano, o que dificulta perceber os limites de atuação da magia e da religião, cuja distinção não é tão evidente. ${ }^{34}$

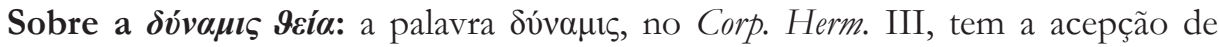

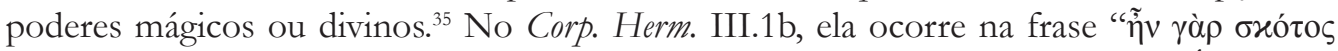

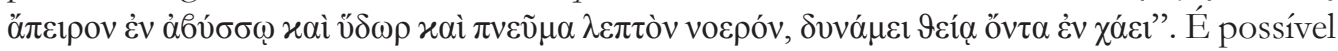
que haja aí uma evocação aos poderes mágicos realizada pelos deuses que se vinculam aos signos. Ainda se menciona, nesse tratado, que o homem foi criado para conhecimento das

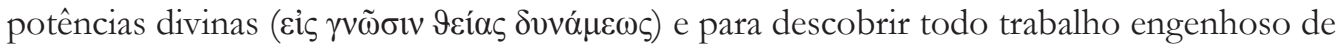

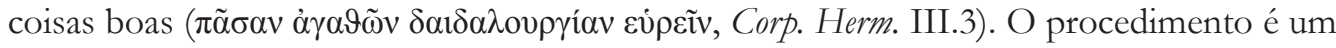
conhecimento dos divinos poderes, dos poderes astrais, extraido dos oráculos advindos dos deuses (Fowden, 1993, p. 79-87). Ao que tudo indica, a cosmogonia do Corp. Herm. III,

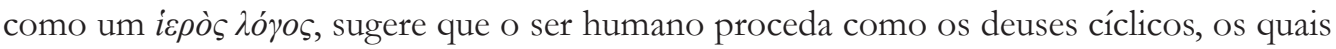

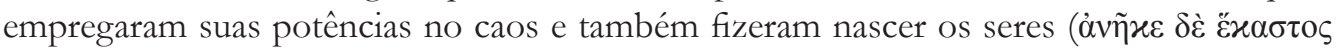

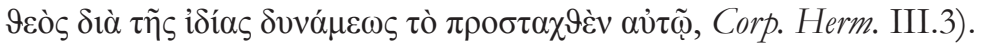

No tratado XII.19 do Corpus Hermeticum, por exemplo, encontram-se as seguintes palavras:

Então todo vivente é imortal por causa dele [do intelecto]; e, dentre todos, o homem, o receptor de Deus e consubstancial com Deus, é o mais [imortal]. Pois Deus conversa só com esse vivente, tanto de noite através de sonhos, quanto de dia através de símbolos [presságios], e lhe prediz todas as coisas futuras através de todas as coisas, de pássaros, de entranhas, de espírito [inspiração], de carvalho; por isso, também o homem procura conhecer as coisas acontecidas antes e as coisas presentes e as coisas futuras (tradução própria). ${ }^{36}$

\footnotetext{
${ }^{34}$ Johnson, 2009, p. 43. Sobre magia, cf. Fowden, 1993, p. 79-87.

${ }^{35}$ Liddell; Scott; Jones, 1996, p. 452.

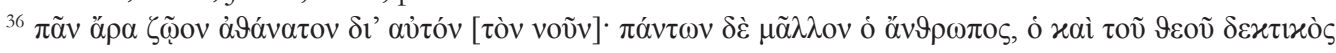

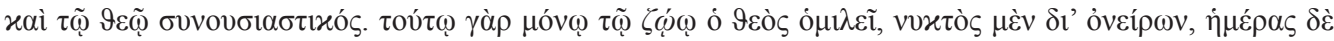


Deveras, se, por um lado, o texto supracitado trata da comunicação entre Deus e o ser humano, o que deveria pressupor oração, contemplação e meditação; por outro lado, o que se vê são técnicas ( $\tau \varepsilon \dot{\chi} \chi v \alpha \imath$ ) mágico-astrológicas, tais como os agouros, os presságios,

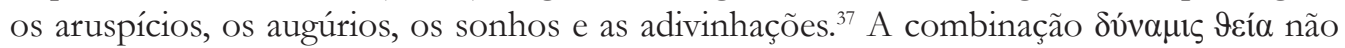
é por acaso. O mago adquire e demonstra o conhecimento do reino divino. Trata-se do

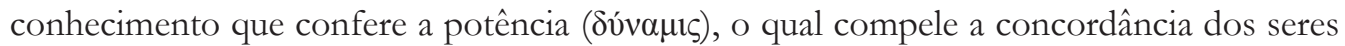

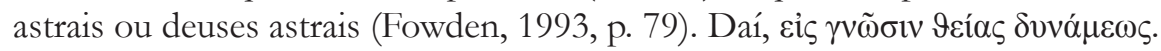

Em suma, a despeito de esse tratado ter influência greco-judaica ou, mais especificamente, estoica e do judaísmo helenístico, pode-se constatar uma relação com os tratados mágico-astrológicos do hermetismo. Como Walter Scott, Charles Harold Dodd e André-Jean Festugière rejeitaram as interações entre os tratados mágico-astrológicos e filosófico-religiosos, negligenciaram a possível influência desses documentos (Hermetica, 1985, v. 1, p. 1; Festugière, 2014, p. 7-8; Dodd, 2005, p. 11). Em última análise, é possível que esse tratado seja uma das mais antigas formas de hermetismo que se preservou no Corpus Hermeticum, pertencendo, assim, ao estrato mais antigo do hermetismo, a saber, o mágicoastrológico (Kee, 1973, p. 239).

\section{REFERÊNCIAS}

ABRÃO, Bernadette Siqueira (org.). História da Filosofia. São Paulo: Nova Cultural, 2004.

ANDERSON JR., R. Dean. Glossary of Greek Rhetorical Terms connected to Methods of Argumentation Figures and Tropes from Anaximenes to Quintilian. Leuven: Peeters, 2000.

ARISTOTELIS Ars Rhetorica. Recognovit brevique adnotatione critica instruxit W. D. Ross. Oxford: Oxford University Press, 1959.

BERTRAND, Denis. Caminhos da Semiótica literária. Bauru: EDUSC, 2003.

BETTS, Gavin. Complete New Testament Greek. 2. ed. London: Hodder and Stoughton; New York McGraw Hill, 2010.

BETTS, Gavin; HENRY, Alan. Complete Ancient Greek. 3 ed. London: Hodder and Stoughton; New York: McGraw Hill, 2010.

BETZ, Hans Dieter et al.(eds.). The Greek Magical Papyri in Translation. Including the Demotic Texts. Chicago; London: University of Chicago Press, 1986.

BLASS, Friedrich; DEBRUNNER, Albert; FUNK, Robert Walter. A Greek grammar of the New Testament and other early Christian literature. 20. print. ed. 1961. Chicago; London: University of Chicago Press, 2009.

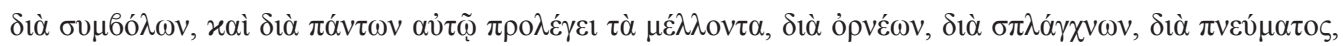

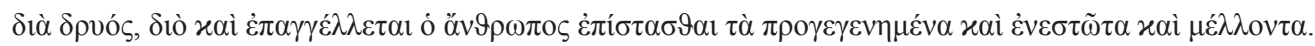

${ }^{37}$ Coulanges, 2004, p. 144, 173-174, 178, 237; Cumont, 1929, p. 151, 176; Frese, 2005, v. 14, p. $9337-$ 9338. 
COPENHAVER, Brian P. Hermetica: The Greek Corpus Hermeticum and the Latin Asclepius in a New English Translation. With Notes and Introduction Brian P. Copenhaver. New York: Cambridge University Press, 2000.

COUlANGES, Fustel de. A Cidade Antiga. Tradução Fernando de Aguiar. 5. ed. São Paulo: Martins Fontes, 2004.

CROATTO, José Severino. As Linguagens da experiência religiosa: uma introdução à fenomenologia da religião. 3. ed. Tradução de Carlos Maria Vásquez Gutiérrez. São Paulo: Paulinas, 2010.

CUMONT, Franz. Les Religions Orientales dans le Paganisme Romain. 4. Ed. revue, illustrée et annotée. Publiée sous les auspices du Musée Guimet. Paris: Librairie Orientaliste Paul Geuthner, 1929.

DEFINA, Gilberto. Teoria e Prática de Análise Literária. São Paulo: Pioneira, 1975.

DELATTE, L.; GOVAERTS, S.; DENOOZ, J. Index du Corpus Hermeticum. Roma: Edizioni dell'Ateneo e Bizzari, 1977.

DODD, Charles Harold. The Bible and the Greeks. London: Hodder and Stoughton, 1954.

DODD, Charles Harold. The Interpretation of the Fourth Gospel. Cambridge: Cambridge University Press, 2005.

EBELING, Florian. The Secret History of Hermes Trismegistus: Hermeticism from Ancient to Modern Times. Forworded by Jan Assmann. Translated from the German by David Lorton. Ithaca and London: Cornell University Press, 2011.

ELIADE, Mircea. História das crenças e das ideias religiosas: De Gautama Buda ao Triunfo do Cristianismo. Rio de Janeiro: Zahar, 2011.

ELIADE, Mircea. Tratado de História das Religiões. 4. ed. São Paulo: Martins Fontes, 2010.

ELIADE, Mircea; COULIANO, Ioan P. Dicionário das religiões. 2. ed. São Paulo: Martins Fontes, 2009.

EUSEBIUS CAESARIENSIS. Praeparatio Evangelica. Lesvos: University of Aegean, 2006.

FERGUSON, Everett. Background of early christianity. Grand Rapids: W. B. Eerdmans, 1990.

FESTUGIÈRE, André-Jean. La Révélation d’Hermès Trismégiste. Paris: Les Belles Letres, 2014.

FILORAMO, G. Hermetism. In: DI BERARDINO, Angelo. Encyclopedia of the Early Church. Cambridge: James Clarke, 1992. v.1, p. 377-378.

FRESE, Pamela R.; GRAY, S.J.M. Trees. In: JONES, Lindsay (ed.). Encyclopedia of Religion. 2. ed. Detroit, MI: Thomson/ Gale, Macmillan Reference, 2005. v. 14, p. 9333-9340.

GONZÁLEZ BLANCO, Antonino. Misticismo y Escatología en el Corpus Hermeticum. Cuaderno de Filología Clásica, n.5, p. 313-360, 1973. 
HERMÈS TRISMÉGISTE. Corpus Hermeticum. Texte établi par A.D. Nock et traduit par A.-J. Festugière. 2. ed. Paris: Les Belles Lettres, 2011.

HERMETICA: the ancient Greek and Latin writings which contain religious or philosophical teachings ascribed to Hermes Trismegistus. Introductions, texts and translation edited and translation by Walter Scott. Boston: Shambala Publications, 1985. v. 1.

HERMETICA: the ancient Greek and Latin writings which contain religious or philosophical teachings ascribed to Hermes Trismegistus. Volume II: Notes on the Corpus Hermeticum by Walter Scott. Boston: Shambala Publications, 1985. v. 2.

HORMAN, John F. The Text of the Hermetic Literature and the Tendencies of its Major Collections. Thesis (Doctor of Philosophy in Religious Sciences). McMaster University. Hamilton, 1973.

HORNA, Konstantin. ' Gnome, Gnomendichtung, Gnomologie'. PWS up, v. 6, cols. 74-87, 1935.

JAY, Eric G. New Testament Greek: An Introductory Grammar. 14. impr. London: SPCK, 1994.

JOHNSON, Luke Timothy. Among the Gentiles: Greco-Roman Religion and Christianity. New Haven; London: Yale University Press, 2009.

JUNG, Carl Gustav; KERÉNYI, Károly. Prolegomeni allo studio scientifico della mitologia. Traduzione italiana da A. Brelich. Torino: Boringhieri, 2012.

KEE, Howard Clark. The origins of christianity: sources and documents. Englewood Cliffs: Prentice-Hall, 1973.

KERÉNYI, Karl. Arquétipos da religião grega. Rio de Janeiro: Vozes, 2015.

LIDDELL, Henry George; SCOTT, Robert. A Greek-English lexicon. Revised and Augmented throughout by Henry Stuart Jones with the Assistance of Roderick McKenzie with the Cooperation of many scholars. With Revised Supplement. Oxford: Claredon Press, 1996.

MAHÉ, Jean-Pierre. Hermès en haute-Egypte: Le Fragment du Discours parfait et les Définitions Hermetiques Arméniennes. Québec: Presses de l'Université Laval, 1982.

MAHÉ, Jean-Pierre. "Hermes Trismegistos". In: JONES, Lindsay (ed.). The Encyclopedia of Religion. 2. ed. Detroit: Thompson/ Gale, 2005. v. 6, p. 3938-3944.

MORWOOD, James; TAYLOR, John (eds.). Pocket Oxford Classical Greek Dictionary. GreatBretain: Oxford University Press, 2002.

PLATÃO. A República. Tradução de Enrico Corvisieri. São Paulo: Nova Cultural, 2004.

PLATO. Republic. Books VI-X. With an English Translation by Paul Shorey. Cambridge MA: Harvard University Press; London: William Heinemann, 1942.

PREISENDANZ, K et al. (eds.). Papyri Graecae Magicae. Die Griechischen Zauberpapyri. Stuttgart: Teubner, 1974 (1928-1931). 
RAGON, E. Gramática grega. Inteiramente reformulada por A. Dain, J.-A. de Foucault, P. Poulain. Tradução de Cecilia Bartalotti. São Paulo: Odysseus, 2012.

REALE, Giovanni. História da Filosofia Grega e Romana. ed. corr. São Paulo: Loyola. 2008.

ROSSETTI, Livio. Introducão à Filosofia Antiga: premissas filológicas e outras "ferramentas de trabalho". São Paulo: Paulus, 2006.

RUSSO, Joseph. Prose Genres for the Performance of Traditional Wisdom in Ancient Greece: Proverb, Maxim, Apothegm. In: EDMUNDS, Lowell; WALLACE, W. (eds.). Poet, Public, and Performance in Ancient Greece. Baltimore; London: The Johns Hopkins University Press, 1977, p. 49-63.

SEPTUAGINTA. Id Est Vetus Testamentum Graece Iuxta LXX Interpretes edidit Alfred Ralfs. 6. ed. Stuttgart: Deutsche Bibelgesellschaft, 1979. Duo volumina in uno.

VAN BLADEL, Kevin. The Arabic Hermes: From Pagan Sage to Prophet of Science. Oxford; New York: Oxford University Press, 2009.

VAN DEN BROEK, Roelof. Hermetism. In: HANEGRAAFF, Wouter J. (ed.). Dictionary Of Gnosis And Western Esotericism. Leiden; Boston: Brill, 2006, p. 558-570.

VAN DEN KERCHOVE, Anna. La voie d'Hermès: Pratiques rituelles et traités hermétiques. Leiden; Boston: Brill Academic Pub, 2012.

YATES, Frances A. Giordano Bruno and the Hermetic Tradition. London: Routledge and Kegan Paul, 1964. 